\title{
Ortolan Bunting Emberiza hortulana at Kvismaren, central Sweden - breeding studies and suggested management
}

\author{
Ortolansparven Emberiza hortulana vid Kvismaren, centrala Sverige- \\ häckningsstudier och förslag till skötsel
}

JAN SONDELL, CRAIG BROOKES \& MAGNUS PERSSON

\begin{abstract}
The only remaining Ortolan Buntings in the province of Närke are about 15 singing males in the Kvismaren valley. We studied this small population intensively during May-June, 2011. We found that the birds depend on bare soil of two kinds: potato fields turning green only in early July and open ground underneath birch and elder vegetation in an old bog. Thus spring sowing may be a "trap" as fields that look optimal when the Ortolans arrive in early May will in a few weeks turn green and become less suitable for breeding. In 2011, 6 pairs likely raised young and this result seems normal. Possibly this very small population persists due to recruitment from the much larger population in northern Sweden, that passes through Kvismaren during spring and autumn migration.

The central Swedish population is only about 100 pairs and will probably disappear if a management plan is not implemented rapidly. New potentially suitable areas must be identified, and optimal breeding conditions must be provided at sites where Ortolan Buntings still occur.

Jan Sondell, Rulleuddsvägen 10, S-178 51 Ekerö, Sweden.E-mail:jan.sondell@telia.com

Craig Brookes, 25 Westfield Rd, Blackpool, Lancs, United Kingdom, FY1 6NU.

E-mail: craig.brookes91@gmail.com

Magnus Persson, Fabriksgatan 56 B, S-412 51 Göteborg, Sweden.E-mail: humlapersson@hotmail.com
\end{abstract}

Received 26 September, Accepted 20 November 2011, Editor: D. Hasselquist

\section{Background}

\section{Population change in Europe, Sweden and at Kvismaren}

In the beginning of the 20th century the Ortolan Bunting Emberiza hortulana was breeding in most of central Europe; at the end of the century, however, breeding areas had significantly declined (Bernady 2009). The population in Norway (Naevia 2002) and southern Finland (Vepsäläinen et al. 2005) had almost disappeared and reductions were recorded in most European countries. In Spain, however, the population increased in areas with young forests after wildfires (Brotons et al. 2008).

The Ortolan Bunting was also present all over Sweden in the middle of the 20th century; the population gradually decreased in southern and central Sweden (Runesson 1996) and also on farmland in northern Sweden. Today Ortolan Buntings mainly breed on opened forest land (clear cuttings) in northern Sweden (The Swedish Bird Survey, Svalan). Furthermore a little residue of around 100 pairs still exists in Närke, Västmanland and Up- pland. The known Närke population is today restricted to the Kvismare area.

At Kvismaren approximately 15 singing males have been counted annually during the last decade (Sondell \& Runesson 2010). According to several censuses we know that in earlier decades the population was much larger (Runesson \& Jönsson 1987). The pairs of Ortolan Buntings present at Kvismaren today breed in open agricultural landscape northeast of the Kvismaren lakes. Males sing from small moraine islets covered by trees and these groves are surrounded by farmland fields of organic soil.

\section{Thinning of forest groves at Kvismaren in 2009-2010}

Föreningen Kvismare Fågelstation, FKF (Society of Kvismaren Bird Observatory) managing the Kvismare Bird station since 1961, has for many years been concerned about the Ortolan Bunting decline (Runesson 1996). In 2009, FKF started to try to improve the situation. The first step in these 
efforts was to boost the nesting habitat. Many of the tree groves possible to use for nesting were engulfed by closed vegetation. In 2009, five islets were cleared (Sondell \& Runesson 2010). Most of the undergrowth was removed and the taller trees were left as song posts with a distance of some 10 metres between. The thinning was repeated for five more islets in 2010 .

\section{SOF project}

In 2011, the Swedish Ornithological Society (SOF) became aware of the severe decline of the Ortolan Bunting population in central Sweden and started a project with the aim to understand the species' breeding biology and to find means to improve its population size. The Kvismaren "Ortolan Bunting project" is now co-ordinated with the SOF project.

\section{Unsown fields in 2011}

A hypothesis proposing that the lack of bare soil is the main reason for the successively decreasing Ortolan Bunting population in central Sweden (Sondell 2009) inspired FKF to start a program where parts of the fields were left unsown in the spring of 2011 (Sondell 2010). This was done at three different farms in co-operation with the SOF's farm project.

A study area was chosen in the area where the Ortolan Buntings were expected to settle. Three farmers were contacted and they were committed to leave in total some 1.5 hectares of arable land unsown in the spring of 2011. These areas were directly connected to the groves where the males had been singing in the previous years. To maintain the open soil it was necessary to harrow weed on the unsown areas one time during the breeding period.

Within and close to the study area, there is a large farm named Bärsta. Production on this farm is focused on potatoes; ca. $25 \%$ of its 350 hectares is used for potatoes every year. Other crops are less important. As the potatoes are planted around mid May the open soil is not fully covered by the potato plants until the beginning of July.

\section{Aims}

The aims of the Ortolan Bunting project at Kvismaren 2011 was to monitor the arriving population to find out in detail how many birds were present, if males were stationary, if females showed up in reasonable numbers and if breeding took place.

Furthermore, we were interested in describing the vegetation at nesting and foraging sites. Based

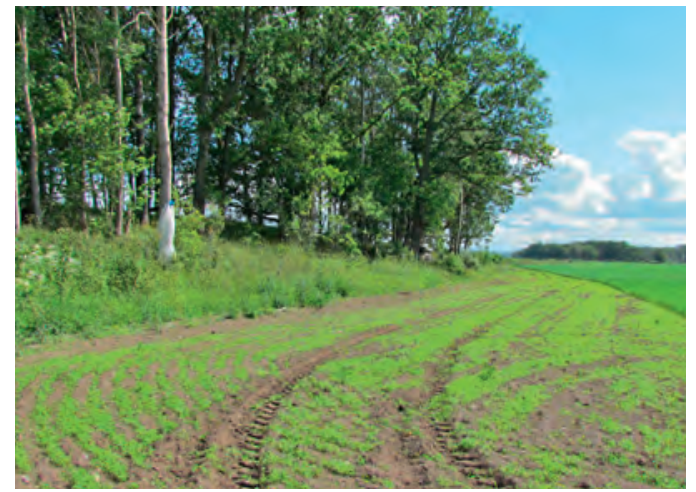

Figure 1. Unsown strip on field of spring seeds near Husön. A nest (A1) was situated in the vegetation in front of the grove at the left. 20 June 2011, the young are newly fledged. Photo Jan Sondell.

Osått körstråk $i$ fält med vårsäd nära Husön. Ett bo (A1) låg $i$ vegetationen framför dungen till vänster. 20 juni 2011, ungarna har just lämnat boet.

on our findings, we also aimed at proposing a management plan with the intention to improve the Ortolan Bunting population in central Sweden.

\section{Methods}

Beginning at the arrival of the Ortolan Buntings in early May, singing, breeding and foraging activities were monitored and all observed activities were registered on maps. Every observation period resulted in a map where all relevant data were gathered. At the end of the observation period, the results were evaluated and the conclusions summarized on maps and in tables.

As a complement to the field studies, data from independent ornithologists accessible at the website Svalan was evaluated. In the Kvismaren area, approximately 70 additional Ortolan Bunting observations were registered at Svalan (SOF bird report site) in the spring and summer of 2011, a frequency of the same magnitude as in earlier years. Most observations were of course parallel to the project observations but still they represent a confirmation of the status of the Ortolan Buntings in Kvismaren and the whole county of Närke. For the "classic" locality in the grove near the Bird Observatory (Ängfallet), we present data on the number of Ortolan Buntings in the years 2005-2011.

Based on the detailed studies in 2011, knowledge of the Ortolan Bunting distribution in Kvismaren 


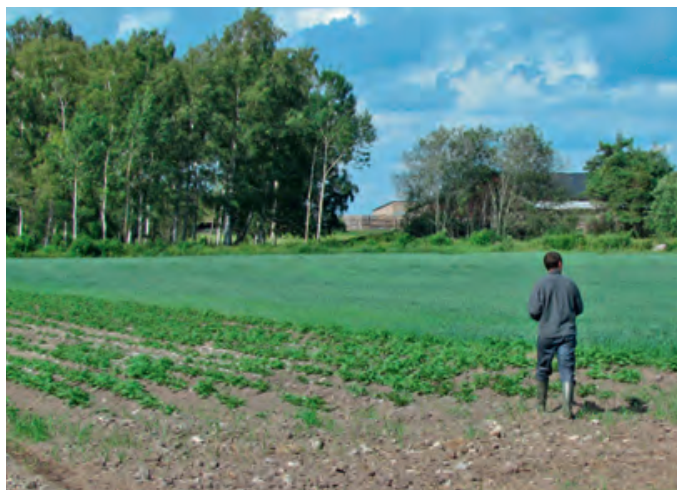

Figure 2. Potato field at Husön, Bärsta, 20 June 2011. Potato containers are stored in the background. Most part of the soil is still uncovered in the potato field. Photo Jan Sondell.

Potatisåker vid Husön, Bärsta, 20 juni 2011. Potatislårar är travade i bakgrunden. Den största delen av marken i potatisfältet är ännu inte täckt av vegetation.

in earlier years, as well as in other parts of central and northern Sweden, a preliminary management plan to improve the Ortolan Bunting population in Sweden has been launched.

\section{Results}

\section{Study area in 2011}

The actual study area, ca 150 ha in size, was defined in April 2011 before the Ortolan Buntings arrived. Most of the groves in the area were thinned in $2009 / 2010$ and three of the landowners were asked to leave 1.5 ha unsown around these groves (Figure 1). When the Ortolan Buntings arrived in late April-early May most of the ground within the survey area was devoid of vegetation. Sowing was under way and in the middle of May most fields within the area started to turn green. This was how-ever not the case for the fields intended for pota-toes or carrots, covering some $20 \%$ of the area. The potato plants did not fully cover the soil until the beginning of July (Figure 2). Furthermore along the southern part of Restamossen (NE part of the study area) the vegetation is rather unique. The for-est roof is exploited by high birches growing fairly sparsely. The undergrowth is however rather thick and consists mainly of red-berried elder Sambucus racemosa. The bushes are fairly dense and under the bushes the ground is partly bare and consists of organic soil (Figure 3).

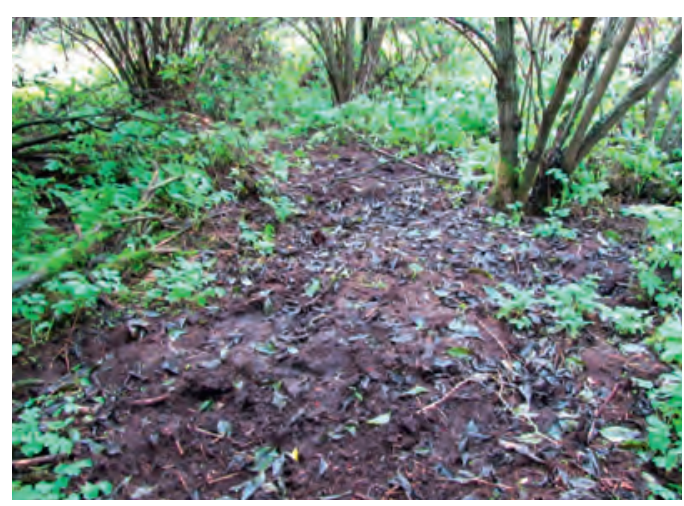

Figure 3. Forest ground at southwestern part of Restamossen (males B4-B6 singing places). The peat soil is partly open underneath the birches and elder bushes. 27 August 2011. Photo Jan Sondell.

Skogsmarken i sydvästra Restamossen 27 augusti 201 (där hannarna B4-B6 sjöng). Mossjorden är delvis bar under björkar och druvfläderbuskar.

\section{Monitoring of the main study area}

The study area was monitored by Craig Brookes and Magnus Persson, on average every third day during the period 26 April-7 June. All Ortolan Bunting activities were registered on maps, and approximately 70 man-hours were used for the field work. The study area and all places with Ortolan Bunting activity are presented in Figure 4 . The first male arrived on 26 April and until the end of the observation period (7 June), 8-14 males and 6-8 females were registered.

Two concentrations of Ortolan Buntings were identified (Table 1, Figure 4). Group A was present in the north-western part and group B in the northeastern part of the main study area. In the southern part no Ortolan Buntings were observed. The Ortolan Buntings used six territories/places in each of the two core areas (A and B). In the A area, A6 was used only once and a male from A1-A5 may have been visiting this place. In area B, possibly B1 and B2 were used by the same pair. Place B3 is a single tree and might be used by some of the other B pairs.

Strong indication of breeding was registered at three places each in the two areas. No attempts to find nests were made because the nests are placed on the ground and are very difficult to find without risking nest damage. Instead, we used observations of birds carrying food into a limited area as a strong 


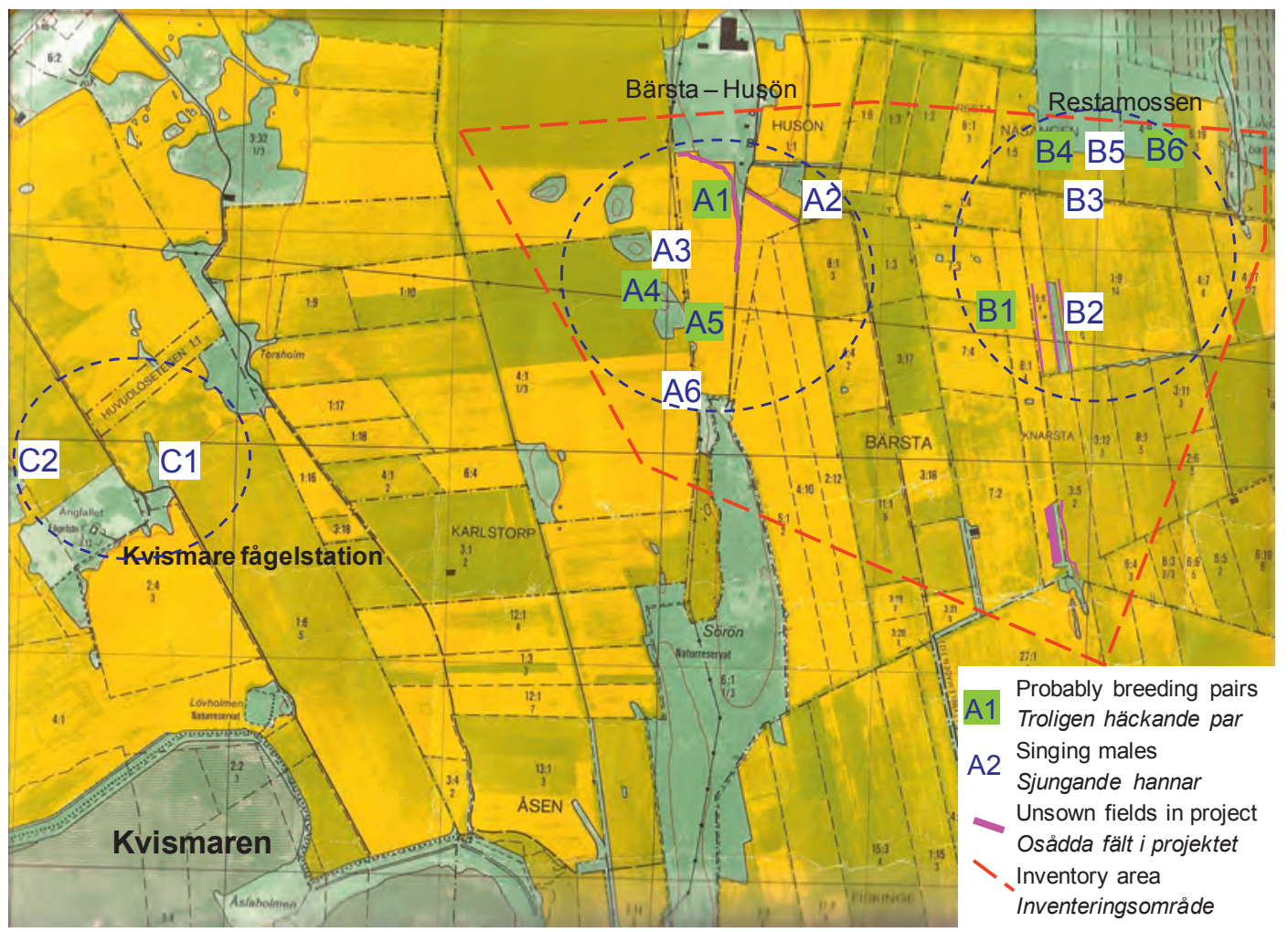

Figure 4. Study area at Kvismaren 2011 for Ortolan Buntings. Areas left unsown are indicated with red and the different Ortolan groves are numbered. Three groups of birds, A-C, was identified.

Studieområde i Kvismaren 2011 för ortolansparv. Osådda stråk är markerade med rött och de olika dungarna med sjungande ortolansparvar är numrerade. Tre grupper fåglar, $A-C$, identifierades.

Table 1 Areas with singing Ortolan Buntings, singing period of males, observations of females, breeding criteria and probable nesting in Kvismaren 2011.

Områden med sjungande ortolansparvar, sångperiod, observationer av honor, häckningskriterier och trolig förekomst av bo i Kvismaren 2011.

\begin{tabular}{lllll}
\hline Observation area & $\begin{array}{l}\text { Dates singing } \\
\text { Sångperiod }\end{array}$ & $\begin{array}{l}\text { Female present? } \\
\text { Hona närvarande? }\end{array}$ & $\begin{array}{l}\text { Breeding criteria } \\
\text { Häckningskriterier }\end{array}$ & $\begin{array}{l}\text { Probable nest } \\
\text { Troligt bo }\end{array}$ \\
\hline A1 Husön, southern part & 3 May-12 June & Yes, several times & Mating, food in bill & Yes \\
A2 Husön SE, small grove & 13 May-3 June & No, male lacking tail & No & No \\
A3 Husön SW, small grove & 13 May-7 June & No & Singing male & No \\
A4 Husön SW, small grove, western part & 3-7 June & Yes & Food to nest & Yes \\
A5 Husön SW, small grove, eastern part & 26 April-7 June & Yes, several times & Food to nest & Yes \\
A6 Sörön, northern tip & 13 May & No & No & No \\
\hline B1 Sörön NE, small grove & 3-7 June & Yes & Pair present & Yes \\
B2 Sörön NE, tree row & 13 May-7 June & No & Singing male & No \\
B3 Husön E, tree at roadside & 9 May-7 June & No & Male present & No \\
B4 Restamossen SW, western part & 9 May-3 June & Yes, several times & Pair present & Yes \\
B5 Restamossen SW, middle part & 20-27 May & Yes & No & No \\
B6 Restamossen SW, eastern part & 9 May-3 June & Yes, several times & Pair present & Yes \\
\hline C1 Ängfallet NE & 30 April-4 July & Yes & Pair seen once & No \\
C2 Ängfallet NW & 10-20 May & No & No & No \\
\hline
\end{tabular}




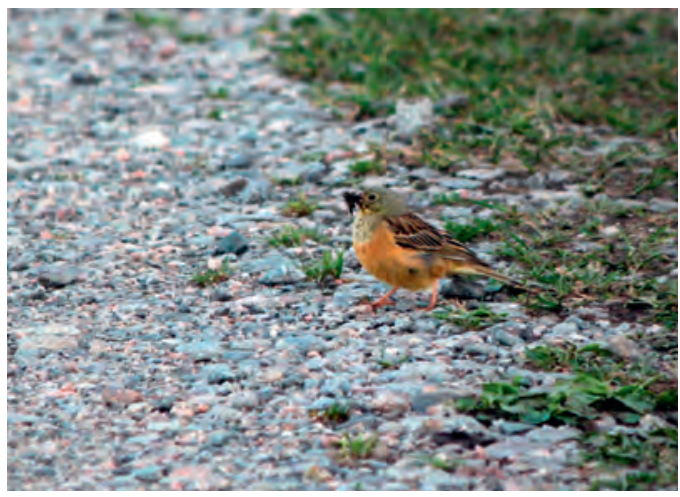

Figure 5. Male Ortolan Bunting (A1) with food for youngsters on the road from Husön to Sörön. Observations such as this have been used as confirmation of a successful breeding nearby. 12 June 2011. Photo Hasse Molin.

Hanne av ortolansparv (A1) med föda till ungarna på vägen mellan Husön och Sörön. Denna observation är en bekräftelse på att fågeln häckar i närheten.

indication that a nest was present in the neighbourhood.

One male had lost his tail (A2). He was observed four times at the same place between 13 May and 3 June; this means he stayed at least three weeks in the same grove. However, there was no indication that this male became paired.

Only a few observations of Ortolan Buntings searching for food were made. One bird was however found on the ground in each of two of the fields where sowing did not take place. In the third southern area with unsown fields no Ortolan Bunting at all were observed in 2011.

At Ängfallet, some $2 \mathrm{~km}$ west of the main study area, two males $(\mathrm{C} 1, \mathrm{C} 2)$ were noted (Table 1, Figure 4). Also a female was reported here on one occasion in the middle of May (by local ornithologists). We did, however, not record any further nesting indications in this area. There were only two additional Ortolan Bunting observations, both on 11 May, reported via Svalan from other parts of the Kvismaren valley (Öby kulle and Löten). Furthermore, in the whole county of Närke, only two more Ortolan Buntings were observed in the spring of 2011.

\section{Ortolan Bunting observations at Ängfallet in 2005-2011}

In 2005-2009 the most convenient locality to spot Ortolan Buntings in central Sweden was probably close to the Kvismare Bird Observatory building (Ängfallet), situated $1 \mathrm{~km}$ south of Norrbyås in Närke. In Table 2, the period of Ortolan bunting records listed at Svalan are shown for the years 2005-2011.

In all years, the Ortolan Buntings have arrived to Ängfallet in the period 30 April-5 May. Most years singing has taken place until the beginning of July. Females have been recorded five out of seven seasons. No clear evidence for breeding has been recorded, but breeding has probably taken place in some years.

Table 2 Time period when Ortolan Buntings were present at Ängfallet, Kvismaren 2005-2011, as well as the maximum number of males and number of females (according to observations reported at Svalan). Types of crops in the surroundings (next to the Ängfallet forest groves) are also presented.

Period då ortolansparvar observerats vid Ängfallet, Kvismaren 2005-2011, samt maximalt antal hannar och antal honor, enligt rapporter till Svalan. Typ av gröda som har omgärdat träddungarna vid Ängfallet är också redovisade.

\begin{tabular}{|c|c|c|c|c|}
\hline $\begin{array}{l}\text { Year } \\
A r\end{array}$ & $\begin{array}{l}\text { Period birds seen } \\
\text { Period med obsar }\end{array}$ & $\begin{array}{l}\text { Max. } \hat{0} \text {, date } \\
\text { Max. ô, datum }\end{array}$ & $\begin{array}{l}\text { Number of }+ \text { present } \\
\text { Antal närvarande }+\end{array}$ & $\begin{array}{l}\text { Type of crops } \\
\text { Typ av gröda }\end{array}$ \\
\hline 2005 & 5 May-19 June & 4 ex: 21 May & 1 ex: 9 June & Hay and spring seeds \\
\hline 2006 & 3 May-3 July & 2 ex: 5 June & 1 ex: 7, 13 May & Hay and spring seeds \\
\hline 2007 & 3 May-27 June & 3 ex: 5 May & 1 ex: 2 June & Hay and spring seeds \\
\hline 2008 & 1 May-23 June & 2 ex: 21 May & - & Hay and spring seeds \\
\hline 2009 & 2 May-14 June & 3 ex: 22 May & 1 ex: 22 May & Hay and spring seeds \\
\hline 2010 & 3 May-12 May & 1 ex: 3 May & - & Hay and autumn seeds \\
\hline 2011 & 30 April-4 July & 2 ex: 14 May & 1 ex: 15 May & Hay and autumn seeds 1 \\
\hline
\end{tabular}

${ }^{1}$ Autumn seeds included several bare areas 
In 2010 the situation was unusual as all fields had been sawn in autumn and a dry spring resulted in no bare soils. The only singing male abandoned the area already 12 May. In 2011 there were no spring sown fields either, but the autumn crops were damaged by hard winter weather and several partly bare soil areas were present, particularly close to Ängfallet.

\section{Discussion}

\section{Kvismaren 2011}

The situation for the Ortolan Bunting in the county of Närke is presently very vulnerable. According to Svalan, Kvismaren is the only area in Närke where Ortolan Buntings are present during the breeding season. However, the Ortolan Bunting is known to suddenly appear or disappear in an area, and it is therefore possible that there can be unknown groups in other parts of the county.

The study area and the number of pairs studied were admittedly small, so even if the 2011 studies were fairly intense, the conclusions made in the present study are based on a small data set. Despite this drawback, there is an urgent need to increase our knowledge about this vulnerable bird species, and all new information is therefore of importance.

The Ortolan Bunting is rather difficult to study. Singing males are fairly easy to find within some $100 \mathrm{~m}$. Females, however, are normally only observed in connection with males. To spot a single female is difficult and nests even more difficult to find. As the nest is built on the ground there is an obvious risk to damage it during nest search. Therefore the best way of obtaining indications of nesting is by observing birds with food in their bill (Figure 5).

In spring 2011, we collected data implying nesting at six sites and between 10-16 territorial males and 6-8 females were counted. All birds except two males and one female were found in the main study area (Table 1, group A and B).

The Ortolan Buntings were very stationary as no males were observed outside the 14 singing posts (12 in the main study area). One male was possible to identify individually as it lacked its tail; this male was only observed within his one singing grove.

The first singing male was heard on 26 April (in A5) and he later bred close to his singing site. Only $37-40 \%$ of the observed individuals were females. As females are more difficult to spot than males, the true proportion of females may be somewhat higher and thus not far off from an even sex ratio.

The 2011 survey result has some positive implications. We have no indications of individuals moving long distances from one song post to another to seek for females. Most males have been present the whole monitoring period at their original song posts. Furthermore, females have showed up in rather good numbers. In south-eastern Norway, where studies were carried out just before the population was extinguished, males moved up to $30 \mathrm{~km}$ in the same season, as almost no females were present (Steifetten \& Dale 2006). Obviously the population at Kvismaren is in a better situation presently. Breeding occurred to an extent that would be expected in a healthy population.

Potentially this positive result could be due to contacts with the population from northern Sweden, which migrates straight over the Kvismaren area. Or alternatively, breeding conditions for Ortolan Buntings may have been unusually favourable in 2011.

\section{Fields sawn is spring - a "breeding trap"?}

The Ortolan Bunting favours groves in open areas with bare soil on its arrival from Africa in the beginning of May. The males take up song posts in the small groves scattered like small "habitat islands" over the large open fields. However, the open bare soil is completely transformed within a few weeks as the seeds germinate and vegetation emerges. Therefore the whole open field landscape changes to become green and areas with bare soil may be very rare. Thus, the spring habitat that appeared perfect for Ortolan Buntings has changed completely into unfavourable "grassland".

In the green surroundings, the ground-feeding Ortolan Bunting may have difficulty finding food to their young. Hence, this situation may constitute a "breeding trap" and lead to low breeding success and an insufficient number of recruits.

It has been suggested that a reason for the declining Ortolan Bunting populations in Scandinavia might be found at migration and/or wintering sites. This is however very unlikely - a Spanish report based on two atlas censuses in Catalonia (19751983 and 1999-2002) strongly contradict this (Brotons et al. 2008). In the Spanish study, the Ortolan Bunting has in general increased and in particular in areas where wildfires have increased in later years. The species has also at the same period been extinct in some areas without fires. Thus, the increase of Ortolan Buntings in Catalonia seems closely connected to a positive development of the 
breeding habitat, rather than caused by changes in winter mortality.

\section{The present situation for the Ortolan Bunting in central Sweden}

The Ortolan Bunting is on the verge of extinction in central Sweden and it will soon disappear if the habitat is not managed in favour of bare soil in spring and early summer. In addition, more research has to be conducted to understand why it cannot produce enough offspring to maintain a stable population size.

In size and shape the Ortolan Bunting resembles its close relative the Yellowhammer, but the two species have totally different strategies of living. The Yellowhammer breeds in the same area of Kvismaren as the Ortolan Bunting but find its summer food amongst trees, bushes and on meadow ground. It stays the winter in Sweden (Fransson \& Hall-Karlsson 2008).

In contrast, the Ortolan Bunting initiates migration as fast as possible after breeding and primary moult, and it spends the winter in Africa south of the Sahara. An early onset of autumn migration seems essential, because most adult individuals suspend the moult of their secondaries allowing them to leave the breeding area earlier (Svensson 1984, Kvismare Bird Observatory, unpublished). In Egypt, on passage, it is found on sandy fields on the edge of the desert (Witherby et al. 1952), where it obviously favours bare soil for feeding.

In earlier decades, when we had small scale farming in Sweden with fallow fields without vegetation, the Ortolan Bunting found bare soil on the unused set-aside fields (probably main feeding habitat), cow tracks, field horse roads, in the vicinity to open dunghills etc. Successively when the farming got more efficient and the farmers stopped leaving bare set-aside fields, the farmland gradually became greener and then followed a gradual decline of the Ortolan Bunting population.

Today the Ortolan Buntings in central Sweden are reported from gravel quarries, energy woods and other forest types with bare soil underneath the trees, industry grounds and on forest clear cuttings (Svalan 2001-2011). The latter habitat is the main habitat in northern Sweden (Sondell 2009) where we still have a fairly stable population of several thousand pairs (The Swedish Bird Survey). Before man started to use the forests in northern Sweden, the main habitat for Ortolan Bunting was probably areas newly burnt by natural forest fires.

\section{Conclusions}

1. The Kvismaren Ortolan Bunting population is very small and vulnerable. It is primarily dependent on areas with open soil in the agricultural landscape. The distribution is presently restricted to the north-eastern Kvismaren valley.

2. An explanation for why this is the only area in the county of Närke where Ortolan Buntings still show up is probably the large scale growing of potatoes on organic soil. Potato farming creates open soil during the breeding period of the species, because the potatoes are planted relatively late in the season. The crops do not cover the ground until the beginning of July when most Ortolan Bunting young have already fledged.

3. The small population at Kvismaren seems to have a stable population size. At least $50 \%$ of the singing males became mated in 2011 and most of the pairs seemed to produce young.

4. Even if the 2011 breeding seasons was good, the fact remains that the Kvismaren population is very small and isolated, and therefore vulnerable to chance effects that may lead to extinction.

5. A positive circumstance is that the relatively large population breeding on forest clearings in northern Sweden is migrating through the Kvismaren area and may possibly contribute with immigrants to the Kvismaren population.

6. If we want to keep a population of Ortolan Buntings in Närke and central Sweden, all means must be taken to enlarge the present population; to start building up a population in another area where no Ortolan Buntings are present today, is probably much more difficult.

\section{Substantial measures}

Below, we suggest a number of measures that must be taken into account if authorities decide to protect the Swedish Ortolan Bunting population. To be able to carry out the actual managements, organisers are needed to be assigned by all county administrative boards concerned, primarily from central Sweden (the counties of Örebro, Västmanland and Uppsala) and northwards.

\section{Core areas of Ortolan Buntings in central Sweden}

In central Sweden, at least some 25 core areas should be identified and actual measures be implemented in these areas. Core areas are defined as areas where at least two males were singing for some 
weeks and were in contact with each other. In these areas, prime open soil must be secured during the period May-June. Observe that the harrowing of weeds may be necessary during the actual period.

By offering the Ortolan Buntings generous areas of open soil, the number of pairs in the core areas may rise and within a couple of years potentially enable expansion.

Inevitably all aforementioned core areas are not yet known. A search for such areas must be conducted as soon as possible and actions quickly undertaken to secure such core areas.

\section{Other potential Ortolan Bunting areas}

Other suitable areas need to be found not too far from the core areas. To establish a totally new population far from areas used by Ortolan Buntings seems very difficult at present. This means that individuals on migration should find an area so attractive that they terminate their migration and start to sing and breed at the actual site. To achieve this, some kind of extra arrangements probably must be undertaken. Unfortunately, we do not yet have the knowledge to create such conditions.

\section{The situation in northern Sweden}

The situation for the Ortolan Buntings in northern Sweden is probably not critical. The main habitat is newly made mechanical clear cuttings. Such measures will result in open areas with scattered trees, and on the ground there will be tracks from the machines, leaving bare soil on $5-10 \%$ of the area.

To know more about the favourite habitats some analysis of data from the Swedish Bird Survey ought to be carried out and the best sites revisited and described in detail.

Maybe it would be possible for the big enterprises in northern Sweden to adapt their cutting methods to the demand of the Ortolan Bunting.

\section{Measures by priority}

1. Open soils during the breeding season is crucial, and to set aside unsown parts of fields (preferably with high humus content) is therefore of absolute top priority. Potatoes growing in the neighbourhoods are an extra advantage. The open soil should be left at the borders of the fields, close to trees/groves that contain potential singing posts and breeding sites. To really improve the habitat, a minimum of 0.5 ha per potential pair should be left unsown. It is better to leave long strings of open soil at the border of the fields and surrounding the groves rather than smaller square areas. Small areas in the middle of the fields are probably of no use for the Ortolan Buntings.

2. Breeding groves or wood edges bordering the actual fields must be present. Undergrowth at the edge should be cleared until approx. 25 metres from the edge and bigger trees should be left fairly sparse in this area.

3. Field roads with gravel are a positive factor (Figure 5). Avoid grass in the centre by preparing the road surface both in spring and autumn. Song posts on wires or big stones are also favoured.

4. Studies with similar aims as in Kvismaren 2011 need to be carried out in the next-coming years to further understand and verify the breeding ecology. The question: how to create a new core area is important to answer.

5. Studies of feeding habits and the species' breeding ecology also need be carried out at forest clear cuttings in northern Sweden to find out how the Ortolan Buntings make use of this habitat and if cutting methods could be adapted to the need of the species.

\section{Acknowledgements}

Thanks to all inventory personnel at Kvismare bird Observatory, to Håkan Johannesson, Patrik Simonsson and Hans Waern who carried out the Sörön bird surveys since 1965 and the students at the Ornithology course at Lund University that conducted field work on Ortolan Buntings in the Kvismaren area in 2005-2010.

This is contribution No. 163 from Kvismare Bird Observatory.

\section{Sammanfattning}

Ortolansparven häckade i hela Västeuropa i början på 1900-talet. Idag har häckningsområdet krympt betydligt (Bernady 2009). Förekomsten i Norge (Naevia 2002) och södra Finland (Vepsäläinen et al. 2005) har nästan upphört liksom i Götaland. I Svealand finns kanske ett hundratal sjungande hannar kvar. I norra Sverige och Finland finns fortfarande tusentals par där de håller till på skogshyggen. Från Spanien har det dock rapporterats att populationen ökat under senare år i skogsområden som varit påverkade av markeld (Brotons et al. 2008). 
Den enda kända ortolansparvpopulationen i Närke återfinns i Kvismaren. Tidigare decennier var arten tämligen allmän (Runesson \& Jönsson 1987). Dagens ortolansparvar finns nordost om Kvismarsjöarna där hannarna sjunger från små trädtäckta moränholmar omgivna av åkrar med organogen jord.

Föreningen Kvismare Fågelstation, FKF som driver Kvismare fågelstation har i många år varit oroad av ortolansparvens tillbakagång (Runesson 1996) och år 2009 startade föreningen att praktiskt försök att göra något åt situationen. Ett första steg var att gallra de åkerholmar som tenderade att växa igen. År 2009 gallrades fem holmar (Sondell \& Runesson 2010) och året därpå ytterligare fem. Den mesta undervegetationen togs bort och större träd lämnades med ca $10 \mathrm{~m}$ avstånd.

En hypotes att "brist på bar jord var den huvudsakliga orsaken till ortolansparvens tillbakagång" har framförts (Sondell 2009) och i ett åtgärdsprogram har det föreslagits att man skall lämna delar av fälten osådda på våren (Sondell 2010). År 2011 lämnade tre lantbrukare ca 1,5 hektar åkermark osådd. Detta skedde i samarbete med SOFs gårdsprojekt. Inom och i närheten av vårt studieområde i Kvismaren är den stora gården Bärsta belägen. Odlingen där är fokuserad på potatis och på ungefär en fjärdedel av den totala arealen (350 hektar) odlas potatis. Eftersom potatis sätts i mitten av maj täcks inte marken helt av potatisblast förrän i början av juli (Figur 2).

\section{Syfte och metodik}

Målsättningen med studierna av ortolansparv i Kvismaren 2011 var att inventera populationen för att i detalj finna ut hur många fåglar som fanns närvarande samt att försöka konstatera $i$ vilken utsträckning häckning ägde rum. Intressanta frågor att besvara var om hannarna var stationära och om tillgången på honor var tillräcklig. Vidare var det av intresse att se hur markvegetationen utvecklades med hänsyn till boplacering och födosök.

Baserat på kunskaperna från 2011 och tidigare år var syftet att också föreslå en skötselplan med avsikt att förbättra förutsättningarna för den svenska ortolansparvpopulationen.

Med början vid artens ankomst noterades aktiviteter som sång, häckning och matning på kartor. Efter fältarbetets slut utvärderades kartorna. Även uppgifter som noterades på Svalan ingick i grunddata. Därifrån erhölls ca 70 ytterligare observationer, de flesta av naturliga skäl liknande de observationer som stationens fältpersonal gjorde.

\section{Resultat}

Det aktuella studieområdet avgränsades i april före ortolansparvarns ankomst. De flesta träddungar i området hade blivit gallrade 2009-2010 och tre markägare lämnade 1,5 hektar mark osådd (Figur 3). När ortolansparven anlände i början av maj pågick vårsådden. I mitten av maj började de flesta fälten att bli gröna. Detta gällde dock inte de ca $20 \%$ av arealen som skulle användas för potatis. På dessa bara ytor täckte inte potatisblasten marken förrän i början av juli (Figur 2).

Vidare fanns i sydvästra hörnet av Restamossen (NO-delen av studieområdet) en unik vegetation av glest stående stora björkar och under dem ett buskskikt av i huvudsak druvfläder Sambucus racemosa. Torvjorden under buskarna var till stor del bar och här fanns två till tre ortolansparvrevir (Figur 3).

Studieområdet inventerades av Craig Brooks och Magnus Persson, i medeltal var tredje dag under perioden 26 april till 7 juni och alla ortolansparvarnas aktiviteter registrerades på kartor. De platser där ortolansparvar sågs redovisas i figur 3. Den första hannen anlände 26 april. Maximalt 14 och minst 8 hannar respektive 6-8 honor registrerades.

Två grupper ortolansparvar kunde identifieras (Tabell 1); grupp A i nordvästra delen av inventeringsområdet och grupp B i den nordöstra delen. I söder fanns inga ortolansparvar detta år. Fåglarna använde sex sångplatser i varje grupp. Goda häckningsindikationer kunde insamlas på tre platser $\mathrm{i}$ vardera gruppen. Eftersom bona är placerade på marken gjordes inget sökande efter bon, då risken att skada dem bedömdes som för stor. Ett par som sågs bära föda i näbben i ett begränsat område utgjorde därför det bästa häckningskriteriet (Figur 5).

En hanne hade förlorat stjärten (A2). Han sågs fyra gånger under perioden 13 maj-3 juni, alltså under tre veckor i samma träddunge. Bara få observationer av födosökande fåglar gjordes. Fåglar sågs dock på marken på vart och ett av de fält som lämnades osådda.

Vid Ängfallet $2 \mathrm{~km}$ väster om studieområdet noterades ytterligare två hannar $(\mathrm{C} 1 \& \mathrm{C} 2$, Tabell 1), och en hona rapporterades därifrån vid ett tillfälle på Svalan. Inga indikationer på bon erhölls dock. Förutom dessa fåglar finns bara två observationer av ortolansparv på andra håll i Kvismaren, och $\mathrm{i}$ hela landskapet Närke noterades bara ytterligare två ortolansparvar på Svalan våren 2011.

Under femårsperioden 2005-2009 var Ängfallet kanske den säkraste lokalen att kryssa ortolansparv i mellersta Sverige. I Tabell 2 listas ortolansparvens 
förekomst vid Ängfallet 2005-2011. Ortolansparvarna anlände varje år under sexdagarsperioden 30 april-5 maj. Honor har noterats 5 av 7 säsonger. Inga häckningar har konstaterats men har säkerligen ägt rum. År 2010 är något avvikande eftersom den enda ortolansparvhannen i dungarna vid Ängfallet slutade sjunga redan 12 maj. Detta år fanns ingen vårsäd omkring Ängfallet (Tabell 2). Vårsäd saknades även 2011 men höstsäden var skadad av den kalla vintern och flera områden med bar jord fanns, särskilt i närheten av Ängfallet.

\section{Diskussion}

Ortolansparvens situation i Närke är verkligen utsatt. Enligt Svalan är Kvismaren det enda område där det finns ortolansparvar under häckningstid i Närke. Möjligen kan det finnas någon oupptäckt grupp av ortolansparvar på andra håll.

Studieområdet och antalet studerade par är litet men tyvärr de enda tillgängliga fåglarna. Även om studien 2011 var relativt intensiv är slutsatserna som dras här alltså baserade på ett litet material. Det är emellertid bråttom att öka kunskapen om denna tillbakadragna arts häckningsbiologi. All tillgänglig kunskap är av betydelse.

Ortolansparven är relativt svår att studera. Sjungande hannar hörs bara några hundra meter medan honor är lättast att finna i närheten av hannar. Eftersom boet läggs på marken är det svårt att finna utan att riskera att det skadas. Bästa indikationen på bo är gamla fåglar med mat i näbben (Figur 5).

Studien identifierade ca 6 häckningar och antalet sjungande hannar var minst 10 och maximalt 16 . Totalt fanns 6-8 honor i området. Alla fåglar utom två hannar och en hona fanns i det huvudsakliga studieområdet (Tabell 1, grupp A och B).

Ortolansparvarna var mycket stationära eftersom ingen fågel observerades utanför de 14 sångplatserna (12 i huvudområdet). En hanne kunde dessutom identifieras individuellt eftersom han saknade stjärt. Han observerades under tre veckor och då alltid i sin ordinarie träddunge.

Proportionen honor var ca. 40\%. Eftersom honor är svårare att hitta är troligen den riktiga siffran något högre, dvs nära 50-50\% könskvot, vilket är relativt normalt för monogama tättingar.

Inventeringens resultat 2011 har några positiva inslag. Vi har inga indikationer på att vissa hannar flyger långa sträckor mellan sångplatser för att söka efter honor, vilket var fallet i södra Norge innan population dog ut där (Steifetten \& Dale 2006). Dessutom uppträdde honor i ett som man kan anta normalt antal. Detta positiva resultat kan bero på att populationen i Kvismaren står i kontakt med de ortolansparvar som flyttar över området från de större populationer i norra Sverige och kanske Finland.

Vårsådda fält - är dessa en "häckningsfälla"? Ortolansparven föredrar öppen jord när den anländer från Afrika efter flyttningen. Hannarna sjunger från små träddungar ute på fälten. Den öppna bara jorden förändras dock ett par veckor efter ankomsten när vårsäden gror. Landskapet blir grönt och öppen jord blir sällsynt. Det habitat som tidigare på våren sett ut att vara perfekt för häckning förvandlas nu helt. I vegetationen har ortolansparven troligen svårt att finna föda. Situationen kan bli till en "häckningsfälla" som kan leda till lågt reproduktionsresultat och över tiden en minskande populationsstorlek.

Som nämnts är ortolansparven på gränsen till utrotning i mellersta Sverige och kommer utan tvivel att försvinna om ingen biotopförbättring äger rum. Det viktigaste är att fullt ut förstå varför den inte kan föda upp tillräckligt många ungar för att bibehålla en stabil population.

I storlek och utseende liknar ortolansparven den närbesläktade gulsparven, men dessa två arter har helt olika livsstrategier. Gulsparven häckar i samma område vid Kvismaren men finner födan bland träd, buskar och på ängsmark. Den övervintrar inom landet (Fransson \& Hall-Karlsson 2008).

Ortolansparven däremot flyttar nästan direkt efter häckningen till tropiska Afrika. Den avbryter ruggningen av vingpennorna för att kunna starta tidigare (Svensson 1984, Kvismare fågelstation, opublicerat). I Egypten återfinns den under flyttning på sandiga åkrar intill ökenkanten (Witherby et al. 1952).

När vi fortfarande hade ett småskaligt jordbruk i Sverige där åkrarna låg i träda ungefär vart fjärde år och det fanns många små fållor, kostigar, hästtrampade körvägar och öppna gödselstackar, upprätthöll ortolansparven sin numerär. Idag är åkrarna större, antalet djur färre och det finns nästan inga fält utan vegetation. Denna omställning har skett gradvis och parallellt med detta har ortolansparven också minskat $\mathrm{i}$ antal.

Idag rapporteras ortolansparv från grustag, industriområden, avverkningsytor, energiskog och annan skog med bar jord under ett trädskikt (Svalan 2001-2011). Skogsavverkningsytor är det klart vanligaste habitatet för arten i norra Sverige (Sondell 2009) och där finns en population på flera tusen par (Svensk Fågeltaxering). 


\section{Slutsatser}

I Närke finns idag ortolansparven bara i ett litet område i Kvismardalen. Förklaringen till att ortolansparven håller sig kvar där är troligen att den storskaliga potatisodlingen i området erbjuder öppen jord och att de häckande paren därför har normal häckningsframgång. Även markskiktet vid Restamossen ger liknande förutsättningar.

Studien 2011 visade att häckningen gick bra och uppenbarligen producerade de häckande paren ungar. Risken är dock stor att denna lilla kvarvarande population inom några år försvinner, kanske på grund av slumpartade faktorer. Ett positivt förhållande är dock att den större populationen på Nordkalotten sträcker förbi Kvismaren och att ett tillskott av individer då sannolikt möjliggörs.

Om vi önskar behålla ortolansparven i Närke och övriga Mellansverige måste konkreta åtgärder vidtas för att förbättra förutsättningarna där. Att försöka bygga upp en population i andra delar av Mälardalen är troligen avsevärt mycket svårare.

\section{Konkreta åtgärder}

Naturvårdsverket har under 2011 gett länsstyrelsen i Örebro i uppdrag att utarbeta en åtgärdsplan för ortolansparven i Sverige. Nedan föreslås ett antal åtgärder för att förbättra förhållandena. För att genomföra åtgärderna är det ytterst viktigt att man länsvis utser personer som kan samordna åtgärderna. De län som berörs är $\mathrm{T}, \mathrm{U}$ och $\mathrm{C}$ län samt länen norr därom.

I mellersta Sverige bör åtminstone 25 kärnområden identifieras och konkreta åtgärder måste vidtas i alla dessa områden. Kärnområden kan definieras som områden där åtminstone två ortolansparvar sjöng inom hörhåll för varandra våren 2011. Troligen är bara 10-15 kärnområden kända idag. Övriga måste upptäckas våren 2012 genom att systematiska inventeringar genomförs. I kärnområdena måste god tillgång på öppen jord erbjudas under perioden maj-juni. Harvning kan bli nödvändig för att hålla jorden fri från ogräs. Genom att erbjuda ortolansparvarna god tillgång på öppen jord och därmed goda reproduktionsmöjligheter bör antalet par inom några år kunna öka.

Andra lämpliga områden bör utväljas inte långt från kärnområdena. Att idag etablera en helt ny population långt från nuvarande områden med ortolansparvar verkar mycket svårt. Någon form av extra åtgärder måste då vidtas, men vad dessa skulle bestå i har vi ännu ingen kunskap om.

Ortolanens situation i norra Sverige är troligen inte kritisk. Det vanligaste habitatet, nyupptagna hyggen, skapas varje år av skogsbrukets föryngringshuggningar. Maskinerna som går på hygget gör spår på 5-10 \% av arealen, vilket troligen gynnar ortolansparven. Exakt hur de utnyttjar hyggena bör studeras för att skogsbolagen möjligen ska kunna anpassa arbetsmetodiken till artens behov.

Åtgärder i prioritetsordning: (1) Identifiera ett kärnområde, lämna minst 0,5 hektar osått per beräknat par i form av stråk längs kanten av fälten i närheten av troliga sångplatser (Figur 1). (2) Skogsholmar lämpliga för häckning röjs, särskilt i brynen mot åkrarna huggs undervegetationen bort. Större träd lämnas med ett avstånd på ca 10 m. (3) Körvägar i åkerlandskapet är positivt. Ytan bör utgöras av grus. Gräsväxt i vägarna bör tas bort genom sladdning ett par gånger per år. Stora stenar och ledningar är positivt som sångplatser. (4) Studier med liknade målsättning som i Kvismaren 2011 bör genomföras även kommande år för att verifiera 2011 års kunskapsläge och ytterligare utöka kunskapen om ortolansparvens häckningsbiologi. (5) Studier bör även genomföras på norrländska hyggen för att se hur ortolansparven utnyttjar dem och för att undersöka om avverkningsmetoderna kan anpassas till artens behov.

\section{References}

Bernady, P. 2009. Ökologie und Schutz des Ortolans (Emberiza hortulana) in Europa - IV. Internationales OrtolanSymposium. Naturschutz Landschaftspfl. Niedersachen, Heft 45, 1-173.

Brotons, L., Herrando, S. \& Pons, P. 2008. Wildfires and the expansion of threatened farmland birds: the ortolan bunting Emberiza hortulana in Mediterranean landscapes. Journal of Applied Ecology 45: 1059-1066.

Dale, S., Steifetten, Ø., Osiejuk, T.S., Losak, K. \& Cygan, J.P. 2006. How do birds search for breeding areas at the landscape level? Interpatch movements of male ortolan buntings. Ecography 29: 886-898.

Fransson, T. \& Hall-Karlsson, S. 2008. Svensk ringmärkningsatlas. Vol. 3. Stockholm.

Nævra, A. 2002. Hortulanens skjebetime. Vår Fuglefauna 25: $62-81$.

Ottvall, R., Green, M., Lindström, Å., Svensson, S., Esseen, P.-A., \& Marklund, L. 2008. Ortolansparvens Emberiza hortulana förekomst och habitatval i Sverige. Ornis Svecica 18: 3-16.

Runesson, B. 1996. Ortolansparven - en nyckfull och lurig rackare. Fåglar i Kvismaren 11: 9-17.

Runesson, B. \& Jönsson, K. 1987. Inventering av gul- och ortolansparv i Kvismaren 1965-86. Fåglar i Kvismaren 2: $2-12$.

Sondell, J. \& Runesson, B. 2010. Ortolansparven i Kvismaren 2009. Fåglar i Kvismaren 25: 21-24.

Sondell, J. 2009. Ortolansparvens habitatval med utgångspunkt i Kvismaren. Fåglar i Kvismaren 24: 2-7. 
Sondell, J. 2010. Ortolansparvens situation i Kvismaren, Närke och plan för eventuella stödåtgärder 2011. Document sent to the County council in 2010.

Svalan. Reportsystem for Birds, Swedish Species Information Centre, SLU.

The Swedish Bird Survey. See: www.zoo.ekol.lu.se/birdmonitoring/res-hackfagel.htm\#Bild17

Svensson, L. 1984. Identification Guide to European Passerines. $3 \mathrm{~d}$ edition. Stockholm.
Steifetten, Ø. \& Dale, S. 2006. Viability of an endangered population of ortolan buntings: The effect of a skewed operational sex ratio. Biological Conservation 132: 8897.

Vepsäläinen, V., Pakkala, T., Phia, M. \& Tiainen, J. 2005. Population crash of the ortolan bunting Emberiza hortulana in agricultural landscapes in southern Finland. Ann. Zool. Fennici 42: 91-107.

Witherby, H.F., Jourdain, F.C.R., Ticehurst, N.F. \& Tucker, B.W. 1952. The Handbook of British Birds, 7th edition. London. 